\title{
Phytochemical Analysis and Hepatoprotective Effect of Hydroethanolic Extract of Stem Bark of Oroxylum indicum
}

\author{
Sushree Sangita Mohapatra ${ }^{1 *}$, R.K. Roy ${ }^{1}$, P. Mohan ${ }^{1}$, T.N. Upadhyaya ${ }^{2}$ and J. Sarma ${ }^{1}$ \\ ${ }^{1}$ Department of Veterinary Pharmacology and Toxicology, College of Veterinary Science, \\ Khanapara, Guwahati-781022, Assam, India \\ ${ }^{2}$ Department of Veterinary Pathology, College of Veterinary Science, Khanapara, \\ Guwahati-781022, Assam, India \\ *Corresponding author
}

\section{A B S T R A C T}

\begin{tabular}{|l|}
\hline Ke y w o r d s \\
$\begin{array}{l}\text { Hepatoprotective } \\
\text { effect, Oroxylum } \\
\text { indicum, Silymarin, } \\
\text { Hydroethanolic } \\
\text { extract }\end{array}$ \\
\hline Article Info \\
\hline $\begin{array}{l}\text { Accepted: } \\
\text { 10 December } 2017 \\
\text { Available Online: } \\
\text { 10 January } 2018\end{array}$ \\
\hline
\end{tabular}

The present study was conducted to evaluate the hepatoprotective effect of the Hydroethanolic extract of the stem bark Oroxylum indicum against $\mathrm{CCl}_{4}$ induced hepatotoxicity. The hydroethanolic extract was prepared. Albino Wistar rats were taken for the study. The extract was prepared at a dose rate of $100 \mathrm{mg} / \mathrm{kg}$ body weight, $300 \mathrm{mg} / \mathrm{kg}$ body weight, $900 \mathrm{mg} / \mathrm{kg}$ body weight. Carbon tetrachloride was used to induce hepatotoxicity. The extract was screened for phytochemical constituents. Enzyme activity of Alanine aminotransamenase, Alkaline phosphatase, Gamma-glutamyltransferase was tested and level of serum total bilirubin and total protein were analyzed. Results found that the shade-dried hydroethanolic bark extract has saponin, tannin, flavonoids, steroids, and glycosides. Biochemical analysis and Histopathological findings revealed the significant $(\mathrm{p} \leq 0.001)$ decrease of liver biomarkers in a dose-dependent manner resulting in the hepatoprotective effect of Oroxylum indicum over the carbon tetrachloride-induced hepatotoxicity and the results of the group treated with $900 \mathrm{mg} / \mathrm{kg}$ body weight were comparable to as of control group. Hydroethanolic extract of $O$. indicum found to have hepatoprotective effect against $\mathrm{CCl}_{4}$ induced hepatotoxicity in Wistar rats.

\section{Introduction}

The liver is the vital and largest internal organ of the body. It performs various kinds of function like metabolism of lipid, fat, protein, foreign compounds etc. its multitasking function makes it essential in the survival of life.

Various drugs like paracetamol, phenytoin, methimazole, rofecoxib and $\mathrm{CCl}_{4}$ have been implicated in various toxicities of the liver. Alcohol consumption is one of the major causes for concern and it is well known that chronic consumption leads to liver cirrhosis. Hepatitis is inflammation of the liver tissue. The most common cause worldwide is virus (Kim et al., 2010). In elucidating the mechanism of the liver damage, therefore, halogenated alkanes such as carbon tetrachloride $\left(\mathrm{CCl}_{4}\right)$ are widely used as a model compound to induce hepatotoxicity and 
elucidate its mechanisms of action following exposure to these compounds.

Oroxylum indicum (L.), belongs to the family Bignoniaceae and is popularly known as Indian Trumpet Flower. The tree is a night bloomer and the flowers are adopte to natural polination by bats (Anonymous, 1972). The literature surveys reavels that in traditional systems of medicine, ifferents parts have been recommended for the treatment of Expectorant, Digestive, Carminative, Febrifuge, Diuretic, Antimicrobial, Antifungal, Anti-inflammatory and Tonic. Leaf decotion was used for treating stomachache, ulcers, Bronchitis, Piles, Jaundice, Leucoderma etc. Seeds are used as purgatives (Warrior et al., 2001; Sankara and Nair, 1972; John, 2001; Anonymous, 1998).

The current study was carried out to evaluate the hepatoprotective effect of a hydroethanolic extract of Oroxylum indicum.

\section{Materials and Methods}

\section{Experimental animals}

The study was conducted in accordance with the guidelines for the use and care of lab animals by Institutional Animal Ethical Care Committee. A total number of 36 Albino Wister rats of 100-120 grams were procured from the Chakraborty Enterprise, Kolkata. All the animals were kept in the clean polypropylene cages in a small group of 6 rats/cage. A total no of 20 mice of either sex of 22-25 grams was taken for the acute toxicity studies. All the animals were given balanced ration and drinking water ad libitum and were maintained in a standard laboratory condition of (12:12 day and night cycle at an ambient temperature of $22-25^{\circ}{ }^{\circ} \mathrm{C}$ ). An acclimatization period of 7 days were given to all the animals before they were subjected to the experiment.

\section{Collection and identification of plant}

Stem bark of Oroxylum indicum and the whole plant of Alternanthera sessilis were collected from the village area of Assam (Kamrup district). The herbarium specimen of Oroxylum indicum was submitted to the Department of Botany, Guwahati University.

\section{Preparation of plant extracts}

For preparing the hydroethanolic extract, 100 grams of powered shade dried stem bark of $O$. indicum were taken and soaked in $70 \%$ ethanol and kept for a period of 4 days for maximum extraction with intermittent stirring. At the end of the fourth day , the content was filtered in muslin cloth, followed by Whatman filter paper no 1 . The extract obtained further subjected to evaporation at $60^{\circ} \mathrm{C}$ in a hot water bath for 24 hours with intermittent stirring.

Phytochemical tests were conducted on the shade-dried powdered stem bark of $O$. indicum and its hydroethanolic extract as per standard procedure (Edeoja et al., 2005).

\section{Acute toxicity test}

Acute toxicity test was carried out according to OECD 425 guidelines and the hydroethanolic extract was found to be highly safe.

\section{Design of experiment}

Group I was given with Normal saline. Group II was given with $\mathrm{CCl}_{4}+$ Liq. paraffin $(50 \% \mathrm{v} / \mathrm{v}$ $2 \mathrm{ml} \mathrm{kg}^{-1}$ body weight $\mathrm{S} / \mathrm{C}$ as Vehicle). Group III was treated with $\mathrm{CCl}_{4}+\mathrm{Liq}$ paraffin $(50 \%$ $\mathrm{v} / \mathrm{v} 2 \mathrm{ml} \mathrm{kg}^{-1}$ body weight $\left.\mathrm{S} / \mathrm{C}\right)+$ Silymarin (100 $\mathrm{mg} \mathrm{kg}^{-1}$ body weight per os). Group IV was treated with $\mathrm{CCl}_{4}+\mathrm{Liq}$ paraffin $(50 \% \mathrm{v} / \mathrm{v}$ $2 \mathrm{ml} \mathrm{kg} \mathrm{kg}^{-1}$ body weight $\left.\mathrm{S} / \mathrm{C}\right)+$ extract of Oroxylum indicum $\left(100 \mathrm{mg} \mathrm{kg}^{-1}\right.$ body weight per os). Group $\mathrm{V}$ was treated with $\mathrm{CCl}_{4}+\mathrm{Liq}$ 
paraffin $\left(50 \% \mathrm{v} / \mathrm{v} 2 \mathrm{ml} \mathrm{kg}^{-1}\right.$ body weight $\left.\mathrm{S} / \mathrm{C}\right)$ +extract of Oroxylum indicum $\left(300 \mathrm{mg} \mathrm{kg}^{-1}\right.$ body weight per os). Group VI was treated with $\mathrm{CCl}_{4}+$ Liq paraffin $\left(50 \% \mathrm{v} / \mathrm{v} 2 \mathrm{ml} \mathrm{kg}^{-1}\right.$ body weight $\mathrm{S} / \mathrm{C})+$ extract of Oroxylum indicum (900 $\mathrm{mg} \mathrm{kg}^{-1}$ body weight per os).

\section{Estimation of liver function}

Estimation of Liver function was carried out by estimation of liver enzymes like Alanine transferase, Alkaline phosphatase, total bilirubin, total protein and gamma glutamyl transferase.

\section{Statistical analysis}

The statistical analysis, two way repeated measures ANOVA in the mixed model was done by SPSS 21.0 software. Repeated measures design uses the same subjects with every branch of research, including the control (Shuttleworth, 2009). For instance, repeated measurements are collected in a longitudinal study in which change over time is assessed. $\mathrm{p}$ $\leq 0.05, \mathrm{p} \leq 0.01$ and $\mathrm{p} \leq 0.001$ is considered as significant.

\section{Results and Discussion}

From the present study, it was found that $\mathrm{CCl}_{4}$ induces the hepatotoxicity by producing free radicals leading to lipid peroxidation and inhibition of ATPase activity (Recknagel, 1983).

\section{Alanine aminotransferase}

In Table 1, the group treated with a hydroethanolic extract of Oroxylum indicum, ALT level in comparison to $\mathrm{CCl}_{4}$ treated group was found to have decreased in a dosedependent manner and was lowest in highest dose of @900 $\mathrm{mg} \mathrm{Kg}^{-1}$ body weight i.e. $66.57 \pm 0.35 \mathrm{U} / \mathrm{L}$ in the $28^{\text {th }}$ day. The result showed a significant difference $(\mathrm{p} \leq 0.001)$ of the ALT level that was found in the liver of the group of animals that were treated with Carbon tetrachloride. The findings of the present study are in agreements with the findings of Bakhta et al., (1999), Rose et al., (2014) and Nasir et al., (2013).

\section{Alkaline phosphatase}

In the Table 2, group treated with the hydroethanolic extract of Oroxylum indicum, ALP level in comparison to $\mathrm{CCl}_{4}$ treated group was found to have decreased in a dosedependent manner and gave a significant result in the highest dose of @ 900mg Kg ${ }^{-1}$ body weight i.e. $260.55 \pm 4.12 \mathrm{U} / \mathrm{L}$ in the $28^{\text {th }}$ day. The result showed a significant difference $(p \leq 0.001)$ of the ALP level that was found in the liver of the group of animals that were treated with Carbon tetrachloride. The findings of the present study are in agreements with the findings of Nasir et al., (2013).

\section{Bilirubin}

In Table 3, the Group treated with a hydroethanolic extract of $O$. indicum also protected the liver in a dose dependent manner and the result was significant at @ 900mg $\mathrm{Kg}^{-1}$ body weight i.e. $0.54 \pm 0.05 \mathrm{mg} / \mathrm{dl}$ at $28^{\text {th }}$ day. The result showed a significant difference $(p \leq 0.001)$ of the serum total bilirubin level that was found in the liver of the group of animals that were treated with Carbon tetrachloride. Similar findings were observed by Asad et al., (2012).

\section{Total protein}

In Table 4, a similar effect of hepatoprotection was found in the group treated with $O$. indicum. The highest dose @900mg/kg bodyweight yielded a result of $5.01 \pm 0.10 \mathrm{~g} / \mathrm{dl}$. The result showed a significant difference $(p \leq 0.001)$ of the total protein level that was found in the liver of the group of animals that 
were treated with Carbon tetrachloride. Similar findings were observed by Tripathy $e t$ al., (2011).

\section{Gama glutamyltransferase}

In Table 5, the group treated with the hydroethanolic extract of Oroxylum indicum, GGT level in comparison to $\mathrm{CCl}_{4}$ treated group was found to have decreased in a dosedependent manner and gave a significant result in the highest dose of @ $900 \mathrm{mg} \mathrm{Kg}^{-1}$ body weight i.e. $2.88 \pm 0.14$ in the $28^{\text {th }}$ day. The result showed a significant difference $(p \leq 0.001)$ of the GGT level that was found in the liver of the group of animals that were treated with Carbon tetrachloride. Hydroethanolic extract of Oroxylum indicum revealed the presence of terpenoids, which constitutes one of the largest families of natural products accounting more than 40000 individual compounds of both primary and secondary metabolisms. Terpenoids have shown to have bioactive principle (Goto et al., 2010). The terpenoids present in the hydroethanolic extract may directly offer hepatoprotective effect, through their free radical scavenging activity.

Table.1 Effect of hydroethanolic extract of Oroxylum indicum on serum enzyme ALT (U/L) in $\mathrm{CCl}_{4}$ induced hepatotoxicity

\begin{tabular}{|c|c|c|c|c|c|}
\hline GROUPS & 0-DAY & 7-DAY & 14-DAY & 21-DAY & 28-DAY \\
\hline $\mathbf{I}$ & $41.25 \pm 1.43$ & $41.86 \pm 1.71 * * *$ & $40.46 \pm 0.82 * * *$ & $43.27 \pm 0.64 * * *$ & $42.10 \pm 0.86^{* * *}$ \\
\hline II & $41.62 \pm 0.39$ & $76.90 \pm 0.43^{\# \# \#}$ & $113.44 \pm 0.60^{\# \# \#}$ & $150.37 \pm 0.69^{\# \# \#}$ & $185.97 \pm 0.76^{\# \#}$ \\
\hline III & $40.86 \pm 0.55$ & $58.99 \pm 0.37 * * *$ & $75.03 \pm 0.48 * * * \# \#$ & $61.35 \pm 0.40 * * * \# \#$ & $45.35 \pm 0.28 * * *$ \\
\hline IV & $41.45 \pm 0.60$ & $73.29 \pm 0.50^{\# \# \#}$ & $101.63 \pm 0.49 * * * \# \#$ & $96.17 \pm 0.65 * * * \# \#$ & $89.27 \pm 0.69 * * * \# \#$ \\
\hline$\overline{\mathbf{V}}$ & $40.60 \pm 0.71$ & $68.24 \pm 1.03 * * * \# \#$ & 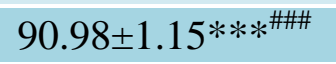 & $84.50 \pm 1.07 * * * \# \#$ & $75.97 \pm 0.93 * * * \# \#$ \\
\hline$\overline{\text { VI }}$ & $41.73 \pm 0.37$ & $67.26 \pm 0.41 * * * \# \#$ & $85.82 \pm 0.51 * * * \# \#$ & $77.38 \pm 0.33 * * * \# \#$ & $66.57 \pm 0.35 * * * \# \#$ \\
\hline
\end{tabular}

*Implies $\mathrm{p} \leq 0.05$ when compared with $\mathrm{CCl}_{4}$, ** implies $\mathrm{p} \leq 0.01$ when compared with $\mathrm{CCl}_{4}$, *** implies $\mathrm{p} \leq 0.001$ when compared with $\mathrm{CCl}_{4}$, \# implies $\mathrm{p} \leq 0.05$ when compared with group given with normal saline, \#\# implies $\mathrm{p}$ $\leq 0.01$ when compared with group given with normal saline, \#\#\# implies $p \leq 0.001$ when compared with group given with normal saline

Table.2 Effect of hydroethanolic extract of Oroxylum indicum on serum enzyme ALP (U/L) in $\mathrm{CCl}_{4}$ Induced Hepatotoxicity

\begin{tabular}{|c|c|c|c|c|c|}
\hline GROUPS & 0-DAY & 7-DAY & 14-DAY & 21-DAY & 28-DAY \\
\hline I & $233.96 \pm 1.28$ & $233.22 \pm 0.72 * * *$ & $232.72 \pm 1.30 * * *$ & $233.12 \pm 1.26 * * *$ & $231.42 \pm 1.09 * * *$ \\
\hline II & $233.60 \pm 1.75$ & $281.94 \pm 2.01^{\# \# \#}$ & $319.52 \pm 2.011^{\# \#}$ & $350.63 \pm 4.63^{\# \# \#}$ & $375.00 \pm 3.08^{\# \# \#}$ \\
\hline III & $7 \pm 3.02$ & $256.41 \pm 2.49 * \# \#$ & $275.78 \pm 2.49 * * \# \# \#$ & $256.50 \pm 2.33 * * * \# \#$ & $238.10 \pm 2.52 * * *$ \\
\hline IV & $233.40=$ & $276.95 \pm 4.50^{\# \# \#}$ & $316.71 \pm 4.50^{\# \# \#}$ & 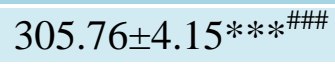 & $293.43 \pm 4.07 * * * \# \#$ \\
\hline$\overline{\mathbf{V}}$ & $232.50 \pm 2.13$ & $272.17 \pm 2.13^{\# \# \#}$ & $306.35 \pm 2.13^{\# \# \#}$ & $291.78 \pm 2.06 * * * \# \#$ & $277.48 \pm 1.71 * * * \# \#$ \\
\hline$\overline{\text { VI }}$ & $233.86 \pm 4.77$ & $266.15 \pm 4.38^{\# \# \#}$ & $295.32 \pm 4.38 * * \# \#$ & $277.22 \pm 4.17 * * * \# \#$ & $260.55 \pm 4.12 * * * \# \#$ \\
\hline
\end{tabular}

*Implies $\mathrm{p} \leq 0.05$ when compared with $\mathrm{CCl} 4$, ** implies $\mathrm{p} \leq 0.01$ when compared with $\mathrm{CCl} 4$, *** implies $\mathrm{p} \leq 0.001$ when compared with CCl4, \# implies $\mathrm{p} \leq 0.05$ when compared with group given with normal saline, \#\# implies $\mathrm{p}$ $\leq 0.01$ when compared with group given with normal saline, \#\#\# implies $p \leq 0.001$ when compared with group given with normal saline 
Table.3 Effect of hydroethanolic extract of Oroxylum indicum on serum enzyme total bilirubin $(\mathrm{mg} / \mathrm{dl})$ in $\mathrm{CCl}_{4}$ Induced Hepatotoxicity

\begin{tabular}{|c|c|c|c|c|c|}
\hline GROUPS & 0-DAY & 7-DAY & 14-DAY & $21-D A Y$ & $28-D A Y$ \\
\hline I & $0.24 \pm 0.02$ & $0.24 \pm 0.08^{* * *}$ & $0.26 \pm 0.01 * * *$ & $0.25 \pm 0.01 * * *$ & $0.28 \pm 0.08 * * *$ \\
\hline II & $0.24 \pm 0.01$ & $0.60 \pm 0.03^{\# \# \#}$ & $1.03 \pm 0.06^{\# \# \#}$ & $1.48 \pm 0.07^{\# \# \#}$ & $1.83 \pm 0.07^{\# \# \#}$ \\
\hline III & $0.29 \pm 0.03$ & $0.46 \pm 0.04^{\# \#}$ & $0.65 \pm 0.04 * * * \# \#$ & $0.53 \pm 0.06 * * *$ & $0.40 \pm 0.04 * * *$ \\
\hline IV & $0.26 \pm 0.02$ & $0.58 \pm 0.03^{\# \# \#}$ & $0.83 \pm 0.05^{\# \# \#}$ & $0.79 \pm 0.06 * * * \# \#$ & $0.77 \pm 0.09 * * * \# \#$ \\
\hline V & $0.24 \pm 0.03$ & $0.57 \pm 0.04^{\# \# \#}$ & $0.80 \pm 0.07^{\# \# \#}$ & $0.74 \pm 0.07 * * * \# \#$ & $0.69 \pm 0.08 * * * \# \#$ \\
\hline VI & $0.22 \pm 0.02$ & $0.50 \pm 0.03^{\# \# \#}$ & $0.72 \pm 0.03 * * \# \#$ & $0.63 \pm 0.04 * * * \# \#$ & $0.54 \pm 0.05 * * *$ \\
\hline
\end{tabular}

*Implies $\mathrm{p} \leq 0.05$ when compared with CCl4, ** implies $\mathrm{p} \leq 0.01$ when compared with CCl4, *** implies $\mathrm{p} \leq 0.001$ when compared with CCl4, \# implies $\mathrm{p} \leq 0.05$ when compared with group given with normal saline, \#\# implies $\mathrm{p}$ $\leq 0.01$ when compared with group given with normal saline, \#\#\# implies $\mathrm{p} \leq 0.001$ when compared with group given with normal saline

Table.4 Effect of hydroethanolic extract of Oroxylum indicum on serum total protein $(\mathrm{g} / \mathrm{dl})$ in $\mathrm{CCl}_{4}$ induced hepatotoxicity

\begin{tabular}{|c|c|c|c|c|c|}
\hline GROUPS & 0-DAY & $7-D A Y$ & $14-D A Y$ & $21-D A Y$ & $28-D A Y$ \\
\hline I & $6.51 \pm 0.11$ & $6.56 \pm 0.09 *$ & $6.82 \pm 0.16 * * *$ & $6.67 \pm 0.14 * * *$ & $6.66 \pm 0.09 * * *$ \\
\hline II & $6.64 \pm 0.14$ & $5.39 \pm 0.17^{\#}$ & $4.89 \pm 0.27^{\# \# \#}$ & $2.01 \pm 0.20^{\# \# \#}$ & $0.93 \pm 0.11^{\# \# \#}$ \\
\hline III & $6.49 \pm 0.11$ & $5.80 \pm 0.10$ & $5.40 \pm 0.14^{\# \# \#}$ & $5.48 \pm 0.13 * * * \# \#$ & $5.63 \pm 0.08 * * * \# \#$ \\
\hline IV & $6.63 \pm 0.08$ & $5.52 \pm 0.27^{\#}$ & $4.94 \pm 0.21^{\# \# \#}$ & $3.75 \pm 0.20 * * * \# \#$ & $4.01 \pm 0.13 * * * \# \#$ \\
\hline V & $6.79 \pm 0.09$ & $5.59 \pm 0.09^{\#}$ & $5.01 \pm 0.17^{\# \# \#}$ & $4.02 \pm 0.17 * * * \# \#$ & $4.59 \pm 0.18 * * * \# \#$ \\
\hline VI & $6.62 \pm 0.12$ & $5.68 \pm 0.20$ & $5.31 \pm 0.20^{\# \# \#}$ & $4.84 \pm 0.08 * * * \# \#$ & $5.01 \pm 0.10 * * * \# \#$ \\
\hline
\end{tabular}

*Implies $\mathrm{p} \leq 0.05$ when compared with $\mathrm{CCl}_{4}, * *$ implies $\mathrm{p} \leq 0.01$ when compared with $\mathrm{CCl}_{4}, * * *$ implies $\mathrm{p} \leq 0.001$ when compared with $\mathrm{CCl}_{4}$, \# implies $\mathrm{p} \leq 0.05$ when compared with group given with normal saline, \#\# implies $\mathrm{p}$ $\leq 0.01$ when compared with group given with normal saline, \#\#\# implies $p \leq 0.001$ when compared with group given with normal saline

Table.5 Effect of hydroethanolic extract of Oroxylum indicum on serum enzyme GGT (U/L) in $\mathrm{CCl}_{4}$ induced hepatotoxicity

\begin{tabular}{|c|c|c|c|c|c|}
\hline GROUP & 0-DAY & $7^{\text {th }}$ DAY & $14^{\text {th }} \mathrm{DAY}$ & $21^{\text {st }}$ DAY & $28^{\text {th }}$ DAY \\
\hline I & $1.33 \pm 0.14$ & $1.28 \pm 0.09 * * *$ & $1.43 \pm 0.06 * * *$ & $1.6 \pm 0.1 * * *$ & $1.5 \pm 0.05 * * *$ \\
\hline II & $1.27 \pm 0.13$ & $3.92 \pm 0.11^{\# \# \#}$ & $4.98 \pm 0.15^{\# \# \#}$ & $5.92 \pm 0.22^{\# \# \#}$ & $6.75 \pm 0.26^{\# \# \#}$ \\
\hline III & $1.25 \pm 0.1$ & $2.76 \pm 0.12 * * * \# \# \#$ & $3.26 \pm 0.17 * * * \# \# \#$ & $2.84 \pm 0.2 * * * \# \#$ & $2.41 \pm 0.17 * * * \# \#$ \\
\hline $\mathbf{I V}$ & $1.33 \pm 0.1$ & $3.41 \pm 0.27^{\# \# \#}$ & $4.94 \pm 0.28^{\# \# \#}$ & $4.61 \pm 0.14 * * * \# \#$ & $4.08 \pm 0.15 * * * \# \#$ \\
\hline $\mathbf{V}$ & $1.19 \pm 0.07$ & $3.31 \pm 0.08^{\# \# \#}$ & $4.7 \pm 0.07^{\# \# \#}$ & $4.38 \pm 0.18 * * * \# \# \#$ & $3.79 \pm 0.19 * * * \# \#$ \\
\hline VI & $1.29 \pm 0.09$ & $2.94 \pm 0.07 * * * \# \# \#$ & $4.09 \pm 0.08 * * \# \#$ & $3.67 \pm 0.11 * * * \# \#$ & $2.88 \pm 0.14 * * * \# \#$ \\
\hline
\end{tabular}


Saponin thought to have the hepatoprotective activity which is demonstrated by the study of Majonoside R2, the major saponin constituent from Vietnamese ginseng (Panax Vietnamese). The main phytochemical constituent was saponin (Tran et al., 2002). The findings suggested that MR2 may have protected the hepatocytes from apoptosis via an inhibition of TNF- $\alpha$ production by activated macrophages and a direct inhibition of apoptosis induced by TNF- $\alpha$. Hydroethanolic extract of both the plants revealed the presence of saponin. The hepatoprotective activity can be attributed to the presence of saponin.

Flavonoids possess a wide spectrum of biological including hypoazotemic, hypotensive, hypoglycemic, anti-inflammatory; anti lipemic and antioxidants activities (Oladele et al., 1995). Flavonoids consist of a group of polyphenolic compounds which is believed to protect the hepatocytes by its free radical scavenging activity. In the present study, the extracts revealed to have flavonoids. Therefore, the hepatoprotective effect of the extracts may be due to its free radical scavenging activity.

\section{Histopathological study}

The hepatoprotective effect of $O$. indicum and silymarin were supported by the Histopathological findings as observed in the Histopathological slides of the liver.

In the $\mathrm{CCl}_{4}$ treated group, extensive fatty changes, centrilobular necrosis, degeneration and lipid peroxidation in all over the hepatocytes were found. Also, the dilatations of central vein and congestion of blood vessels and central vein were observed in the liver.

The group treated with silymarin and $\mathrm{CCl}_{4}$ shown the recovery of the damaged hepatic cells and regenerated hepatocytes were found. There were very less fatty changes which showed that there was the recovery of hepatocytes by the use of silymarin. The treatment with a low dose, moderate dose and a high dose of the plant extract indicated the ascending trend of neutralizing the effects of $\mathrm{CCl}_{4}$. This was evident from the Histopathological alterations observed in the liver of treated rats. These observations indicated that the plant extract was hepatoprotective. The findings of the present study are in agreements with the findings of Pingale (2010) and Tripathy et al., (2011).

From the above experiment, it can be concluded that the hydroethanolic extract of Oroxylum indicum possesses the hepatoprotective activity and the values are comparable to the results produced by Silymarin.

\section{Acknowledgement}

The authors are thankful to College of Veterinary Science, Guwahati for the support of the current study. The authors are thankful to the Department of Pharmacology and Toxicology, College of Veterinary Science, Khanapara for their support for the research work.

\section{References}

Anonymous: 1972. The Wealth of India, Raw Materials; VII. CSIR: New Delhi; p.107.

Anonymous: The Ayurvedic Pharmacopoeia of India.1998. Government of India, Ministry of health and Family Welfare department of Indian system of medicine and Homeopathy, New Delhi, pp. 209215.

Asad, S.B., Iqbal, M.M. and Md. Ibrahim. 2012. Hepatoprotective and nephroprotective effect Phyllanthus amarus seed extract. Annals of Phytomedicine, 1(2): 97-104.

Bhakta, T., Mukherjee, K.P., Banerjee, S., Mandal, C.S., Maity, K.T., Pal, M. and Saha, B.P. 1999. Evaluation of hepatoprotective activity of Cassia Fistula leaf extract. Journal of Ethnopharmacology., 66(3): 277-282.

Edeoja, H.O., Okwu, D.E. and Mbaebie, B.O. 2005. Phytochemical constituents of some Nigerian medicinal plants. Afri. J. Biotechnol., 4(2):68-69 
Goto T., Takahasi, N., Hirai, S. And Kawada J. 2010: Various terpenoids derived from Herbal and Dietary Plant Function as PPAR Modulators and Regulate Carbohydrate and Lipid Metabolism. PPR Research. Vol. 2010, Article 10483958

John A.P. Healing Plants of PeninsularIndia. In: Bignoniaceae. CABI publishing $\mathrm{CAB}$ International Wallingford, UK. 2001; p.169.

Kim, H.Y., Kim, J.K., Choi, J.H., Jung, J.Y., Oh, W.Y., Kim, D.C., Lee, H.S., Kim, Y.S., Kang, S.S., Lee, S.H. and Lee, S.M. 2010. Hepatoprotective Effect of Pinoresinol on Carbon TetrachlorideInduced Hepatic Damage in Mice. $J$ Pharmacol Sci., 112:105 - 112.

Nasir, A., Abubakaer, M.G; Shehu, R.A; Aliyu, U. And Toge, B.K. 2013. Hepatoprotective effect of the aqueous leaf extract of Andrographis paniculata Nees against carbon tetrachloride induced hepatotoxicity in rats Nig. J. Basic Appl. Sci., 21(1): 45-54

Oladele, S.B., Ayo, J.O. and Adaudi, A.O. 1995. Medicinal and physiological properties of flavonoids, coumarin derivatives and anthraquinones of plant origin, West African Journal of Pharmacology and Drug Research; 11:134-144

Pingale, S.S. 2010. Hepatoprotection by Acacia catechu in $\mathrm{CCl}_{4}$ Induced Liver Dysfunction. International Journal of Pharmaceutical Sciences Review and Research, 5(1):51-64.

Recknagel, R.O. 1983. A new direction in the study of $\mathrm{CCl}_{4}$ hepatotoxicity. Life Sci.,
33:401 (cited in Muraleedhara, K. and Gini, C.K.2008. Antioxidant activity of Aulosira fertilisima on $\mathrm{CCl}_{4}$ induced Hepatoxicity in Rats. Indian J. Exp. Biol., 46:52-59).

Rose, H.M., Sudha, P.N. and Sudhakar, K. 2014. Effect of antioxidants and hepatoprotective activities of methanol extract of beetroot against carbon tetrachloride-induced hepatotoxicity in rat models. I J Pharmacol Sci and Res, 5(6): 2546-2555

Sankara S., Nair A.G.R. 1972. Flavonoids of the stem bark of Oroxylum indicum. Curr. Sci. -a; 41: 62-63.

Shuttleworth, Martyn (2009-11-26). Repeated Measures Design. Experimentresources.com. Retrieved 2013-09-02.

Tran, Q.L., Adnyana I.K; Tezuka Y., Saiki I., Krurashige, Y., Tran, Q.K. Kadota, S. 2002. Hepatoprotective effect of Mjonoside R2, the major saponin from Vietnamese gingsang (Panax Vietnamese). Planta med., 68(5):402-6.

Tripathy, B.N., Panda S.K., Sahoo, S; Mishra, S.K. and Nayak L. 2011. Phytochemical analysis and hepatoprotective effect of stem bark of Oroxylum indicum (L) Vent. on carbon tetrachloride-induced hepatotoxicity in rat. International Journal of Pharmaceutical \& Biological Archives, 2(6):1714-1717.

Warrier P.K., Nambiar V.P.K., Ramankutty C. 2001. Oroxylum indicum. In: Warrier et al., (eds.) Indian medicinal Plants 4, Orient Longman Ltd., Madras. Pp.186.

\section{How to cite this article:}

Sushree Sangita Mohapatra, R.K. Roy, P. Mohan, T.N. Upadhyaya and Sarma, J. 2018. Phytochemical Analysis and Hepatoprotective Effect of Hydroethanolic Extract of Stem Bark of Oroxylum indicum. Int.J.Curr.Microbiol.App.Sci. 7(01): 1000-1006.

doi: https://doi.org/10.20546/ijcmas.2018.701.120 